\title{
Neem Crude Extract as Potential Biopesticide for Controlling Golden Apple Snail, Pomacea canaliculata
}

\author{
Rosdiyani Massaguni and Siti Noor Hajjar Md Latip
}

Additional information is available at the end of the chapter

http://dx.doi.org/10.5772/48626

\section{Introduction}

Paddy is the staple food of more than $60 \%$ of the world population, and mainly produced and consumed in the Asian region which over $90 \%$ of the crop grown in Asia. In Malaysia, the cultivation of paddy rice have covers 204,246 ha area of land and principally planted in the eight granary areas; Muda Agricultural Development Authority (96,558 ha), Kemubu Agriculture Development Authority (32,167 ha), Kerian Sungai Manik Project (27,829 ha), Northeast Selangor Project (18,482 ha), Penang Integrated Agricultural Development Project (10,305 ha), Seberang Perak (8,529 ha), Kemasin Semerak Integrated Agricultural Development Project (5,220 ha) and North Terengganu Integrated Agricultural Development Project (5,156 ha) [1]. Most of the paddy in Malaysia is planted as wet paddy, while dry land paddy is very small acreage, and mostly in Sarawak and Sabah. The continuously increasing population caused the increase of the volume in production of rice is an immediate requirement in Malaysia, in order to attain self-sufficiency in food. Since the possibility of extending area under cultivation has practically been exhausted, the only alternative is to enhance crop productivity per hectare. However, achieving this task seems impossible due to various obstacles. One of the main problems is the paddy field has been destroyed by many weeds and pests, such as insects, birds, rodents, and snails especially golden apple snail.

The golden apple snail is a freshwater mollusc that native from Northern Argentina and Southern Brazil [2]. The intention of its introduction in Asia in early 1980s, it has been considered for use as an aquaculture species that provide dietary high-protein supplement for local consumption and as an income earner for the rural poor [3]. Unfortunately, the low market value due to the unexpectedly poor consumer reception resulted in the elimination of its existence in Taiwan [4]. Nevertheless, many snail-farming projects were abandoned 
and the golden apple snail escapes into irrigation ditches and the natural waterways, and subsequently it invaded the rice fields. The initial introduction is thought to have been from Argentina to Taiwan, but by 1982, the golden apple snail had been introduced from Taiwan to the Philippines and continued to China (1985), Korea (1986), Sarawak and Peninsular Malaysia, Malaysia (1987), Java and Sumatra, Indonesia (1989), Thailand (1989), Vietnam (1989) Hong Kong (1991), Laos (1992), and Cambodia (1995) [5]. The golden apple snail has been reported as an important pest of paddy rice in all of these countries and the damage is clearly sufficiently serious to warrant major concern.

In Malaysia, reference [6] was reported that this golden apple snail was firstly presented to be the caused of rice field's damage in 1992 when it was first seen in Keningau, Sabah. After a year from the first invasion, it devastated to Selangor state with an estimated damage about 48 ha of irrigated rice. The golden apple snail was then spread rapidly to other rice growing areas which able to establish easily and rapidly in wet lowland areas where as the water is stagnant and shallow. Once this pest infested in new areas, it was difficult to manage due to its biological and morphological characteristics [7]. According to reference [2], the characteristic possess by golden apple snail such as high fecundity, voracious appetite, fast growth and reproduction, and able to aestivate in soil during dry season have led to its rapid multiplication and widespread distribution. A female snail start to lay eggs at two months old and can laid 50-500 eggs per cluster at one time, with $80 \%$ hatchability rate and the incubation ranges from 10 to 15 days characteristics [7]. An adult of golden apple snail can live up to 3 years with the size up to $3 \mathrm{~cm}$ in height. In addition, it also has a gill and a lung-like organ which make it being able to survive in and out of water. It also can withstand drought for several months by closing its operculum and aestivate in the soil.

Golden apple snail was reported as a major and serious pest in paddy field as it can caused severe damages by completely eliminate the young leaf and stem from plant bases which will result in the death of damaged plants $[5,8]$. It cuts the base of young seedlings with its layered tooth (radula) and munches on the succulent tender sheath of rice. The damage intensity of the infestation are depends on snail density and size and the growth stage of the rice plant [9]. Reference [10] reported that crop stand was reduce by over $90 \%$ when a density of golden apple snail is 8 per $\mathrm{m}^{2}$ with the size of snail is from 10 to $40 \mathrm{~mm}$. The golden apple snail are most damaging to young rice seedlings which is up to 15 days after transplanting because the young, tender leaves and stems favour the snail's feeding habits [11]. This snail is a nocturnal herbivore which unlike as other species of slugs of water and land, where it has a highly voracious appetite. Reference [12] has stated that it can consume a blade of rice in just 3 to 5 minutes. They can even consume the young seedling in a whole field overnight and the obvious signs of severe damage are characterized by missing hills and floating fragments of rice plants. It can destroy newly transplanted or direct-seeded rice as long as there is water in the field.

Therefore, the successful establishment and invasion of the golden apple snail in irrigated rice systems have led to significant economic damage. Farmers in the infested areas are faced with the options of paying additional costs to control the spread of golden apple snail, replanting damaged areas of paddy, or ignoring the problem all together at the risk of 
potentially large yield losses. The economic analysis on yield losses and severe damage cause by golden apple snail was reported by [10] and [13]. Reference [10] reported the yield loss of rice by golden apple snail in Philippines for year 1990 was at 70,000 to 100,000 tons valued at US\$12.5-17.8 million. The total cost due to the golden apple snail including yield loss, replanting cost and the cost of control such as molluscicides and handpicking was estimated at US\$28-45 million. According to another estimate on cost of control the golden apple snail in two countries; Japan and Philippine which farmers spent US\$64,385 and US\$10 million respectively only for pesticides [13].

There are a diversity of management approach has been conducted, including chemical, biological, physical, and cultural methods in order to prevent losses due to these pests. These pests can be effectively controlled by application of pesticides, however, this has longterm toxicity effects, particularly for livestock grazing on pastures following rice production, fish population and also will effect on human health. In another study, cultural control practices were investigated for control of pest population which includes mixed cropping, planting methods (transplanting or direct seeding), age of seedlings at time of transplanting, water management, fertilizer management, crop rotation, number of rice crops per year, planting time, synchronous or asynchronous planting over a given area, trap crop, tillage, weeding and growth duration of the crop. The selection of a particular control method or a combination of methods will depend largely on the management strategy to be adopted which in turn depends on the nature of the paddy rice industry being affected and the costs versus benefits of the whole operation.

Cultural and mechanical control methods will make the environment less favourable for the golden apple snails to establish their colonies. Wire mesh grills were highly recommended to construct at water inlets which it can minimize the entry of golden apple snail into the rice fields and prevent invasion of golden apple snails, but small snails can still enter unnoticed. Hand picking of eggs and destroying of golden apple snails to reduce population levels are highly labour intensive practices and unfeasible in large paddy fields. Among the recommended cultural control measures; crop establishment, planting methods, seedling rate, good leveling the field to remove snail refuges and facilitate drainage, planting at higher densities, burning straw, are the most used methods whereas farmers have started to use older seedlings (more than 30 days old) as a way of minimizing golden apple snail damage [14]. Reference [15] also reported that the use of roto-tiller during plant preparation is beneficial as it resulted to about $27 \%$ golden apple snail mortality as compared to the unploughed fields.

The golden apple snail can be utilized as an animal feed and considered as a replacement for duck and fish meal. Herding duck in paddy fields during the fallow period is advised because ducks was consumed snail's shell and meat. Therefore, duck herding together with feed supplementation during their confinement can increase the side income for paddy farmers. However, [16] was stated that this method was not practical in some areas such as Japan whereas there is little market for duck in Japan. Another biological agent is fish which a carp with pharyngeal teeth has a high potential for preying on golden apple snails. However, utilization of fish may not be practical, since fish culture requires keeping deep 
water in fields [13], but this is often not compatible with modern farming methods. Natural enemy fauna against golden apple snail are very poor in paddy fields and, thus, population explosions of golden apple snail always occur there.

These methods are only partially effective and very labour intensive. Chemicals are still used extensively and inappropriately. Rice farmers mostly rely on commercial available synthetic molluscicides for the immediate control of the golden apple snail in lowland rice fields, without considering the toxic hazards to themselves and non-target organisms. Reference [12] was stated the most common synthetic insecticides used are Brestan ${ }^{\circledR}$ (Triphenyl tin acetate), Aquatin (triphenyltin chloride) and Namekill ${ }^{\circledR}$ (metaldehyde). Reference [17] and [18] were added another molluscicides which is niclosamide (2',5dichloro-4'-nitrosalicylanilide), recommended for control of golden apple snail in transplanted and direct-seeded rice while metaldehyde has been found to be effective in controlling golden apple snail in transplanted. However, this chemicals were used abusively that causing excessive environmental pollution and extremely toxic to non-target organisms. For example, niclosamide which is the only compound recommended for the control of aquatic snails by the World Health Organization (WHO) is effective against golden apple snail at $0.5-1.0 \mathrm{mg}$ a.i./L, but the $\mathrm{LC}_{50}$ for carps is only $0.14 \mathrm{mg}$ a.i./L [5].This means that no fish must be present in the rice fields while the product is applied. Furthermore, the cost of niclosamide in Malaysia is about RM85-95/ha, which is unaffordable to many farmers.

Therefore, the new approach emphasized on environmentally friendly control measures was adopted to replace the chemical oriented control program such as biopesticide or botanical pest control [16]. Botanical pesticide is a biopesticide which extracted directly from the plants that contain toxic compound which use for pest control. It was slow-acting crop protectants which provide an alternative to the synthetic pesticides [19]. Regarding botanical pesticides, a recent review shows that although some plants are used locally against golden apple snail, very little research has been published [5]. In the Philippines, the use of botanicals has been focused recently not only for insect pests but also for golden apple snail control. Reference [20] had found that use of eco-friendly pesticides of plant origin is safer not only to users but also to non-target organisms and the environment in general. As many plant products have been reported to possess pest control properties in various crop plants. Hence, in recent years there is an increased awareness on the use of plant products in pest management strategies such as Derris elliptica [21], Curcuma longa, Blumea balsamifera [22], Phytolacca dodecandra [23], Melia azedarach [24], Nicotiana tabacum [25], Chenopodium quinoa [5], Azadirachta indica [26], Barringtonia racemosa [27], Blumea mollis and Hygrophila auriculata [28].

The neem tree known botanically as Azadirachta indica A. Juss. belong to family Meliaceae, tribe Melieae and the genus Azadirachta is a tropical evergreen related to mahogany. The tribe Melieae are consists of two genera Azadirachta and Melia. Reference [29] were reported the species belonging to Melia genus are distributed in Indo-Myanmar, Indonesia, Philippines, China, Fiji, Malaysia, Mexico and Africa. Melia azedarach Linn. also called as 'gora neem' or 'bakayan' (Persian Lilac) is often confused with neem (Azadirachta indica A. Juss). However, these two species are quite different, the former being a native of Middle 
East. Reference [30] reported two varieties of neem Azadirachta indica A. Juss which one of it is Azadirachta indica Juss var. Siamensis Valeton (Siamese neem tree). This variety was found throughout South-east Asia (Cambodia, Laos, Myanmar and Thailand). The siamensis variety is phenotypically different from the Indian variety and is characterized by less branching, longer and thicker leaflets, a larger and denser inflorescence and larger fruit.

This plant is native to the coastal fringe forests of the drier tropical region of east India, Sri Lanka and Burma. It is currently widespread in Pakistan, Myanmar, Thailand, Malaysia and Indonesia [31]. The neem tree is undemanding and grows well on moist, dry, stony, clayey or shallow soils. Therefore, it is able to grow almost anywhere in the lowland tropics. However, it generally performs best in areas with annual rainfall of 400-1,200 mm [32]. Extracts or crude parts of neem often used for protecting stored grains against insects by mixing them together with seeds. Reference [33] was found that the leaf powder, the seed oil and all kinds of extracts do indeed have a negative effect on the seed-eating insects. However, if this plant parts are used to treat stored seeds against insects, the mammalian consumer of these seeds especially human ought not to be affected by residues of this treatment.

Neem appears to be safe for humans and the environment as it has not been found to possess toxic compound. Reference [34] was stated that neem has oral $\mathrm{LD}_{50}$ in rats of $>5000$ $\mathrm{mg} / \mathrm{kg}$ which making it essentially nontoxic to mammals. In fact, neem leaves and other plant parts are valued for their therapeutic properties and extensively used for medicinal especially in India. Reference [35] reported that many disorders like inflammation, infections, fever, skin diseases, dental disorders and others have been treated with different parts of neem tree. In addition, neem also exhibits a wide range of pharmacological activities such as blood sugar lowering properties, anti-inflammatory, antihyperglycaemic, antiulcer, antimalarial, antifungal, antibacterial, antiviral, antioxidant, antimutagenic anticarcinogenic and immunomodulatory [33].

Nowadays, the dependency on synthetic chemicals has prompted the large scale synthesis of newer chemicals. Eventhough these synthetic pesticides valued for effectiveness and convenience but it also pose certain problems including phytotoxicity and toxicity to nontarget organisms, environmental degradation and health hazards to farmers. In addition, they also may accelerate development of resistant pests to specific pesticidal chemicals.

Therefore, the cost-effective, nontoxic, biodegradable, eco-friendly and botanical 'soft pesticides' are the need of present day agriculture as an alternative to hazardous and recalcitrant synthetic pesticides [35]. Neem was stated on the tops of the list of 2,400 plant species that are reported to have pesticidal properties and is regarded as the most reliable source of eco-friendly biopesticidal property. Neem based pesticides are systemic in nature which have no ill effects on humans and animals, and have no residual effect on agricultural produce. Besides, it is also easy to prepare, cheap and highly effective and thus constitute as an important source of pesticide for economically poor farmers.

There are a lot of researches have been done to discover and determine the potential of neem as a biopesticide in against a variety of rice insect pests. Reference [36] reported the 
effects of two different neem products (Parker Oil ${ }^{\mathrm{TM}}$ and $\mathrm{Neema}^{\circledR}$ ) on mortality, food consumption and survival of the brown planthopper (Nilaparvata lugens) were studied in the field. The experiment with nymph and adult reared in cages that set out in the paddy field showed immediate mortality after treatment application. The results clearly indicate the neem-based pesticide (Parker Oil ${ }^{\mathrm{TM}}$ and Neema ${ }^{\circledR}$ ) containing low lethal concentration can be used effectively to inhibit the growth and survival of Nilaparvata lugens. Besides, reference [15] and [37] also have reviewed the effectiveness of neem insecticidal properties that successfully against white-backed planthopper (Sogatella furcifera), green leafhopper (Nephotettix virescens) and the rice water weevil (Lissorhoptrus oryzophilus).

Reference [12] tested aqueous neem leaf and seed extracts, neem oil and Bioblitz (EC formulation) against golden apple snail in the laboratory. Leaf and seed extracts were the most toxic causing $100 \%$ snail mortality at 100 ppm after 48 hours. Aqueous neem seed and leaves extract was tested against golden apple snails in the field (Rejesus and Punzalan, 1997). Treatment with concentration 20, 90 and $100 \mathrm{~kg} / \mathrm{ha}$ of neem seeds were the most effective aqueous extract which inhibited feeding of the golden apple snails. However, effects of neem treatments on the ecology of the golden apple snails are still to be investigated.

In Thailand, reference [38] revealed the toxicity of leaf crude extracts from neem tree and garlic (Allium sativum L.) on mortality rate of golden apple snails at concentrations of 50, 250, 500, 750 and $1000 \mathrm{mg} / \mathrm{l}$. High concentration of neem tree leaf extract $(1000 \mathrm{mg} / \mathrm{l})$ killed $95.83 \%$ of golden apple snail in 95 hours and high concentration of garlic (1000 mg/l) killed $91.66 \%$ of golden apple snail in 96 hours.

Besides against rice insect pests, neem also has shown activity on a wide range of insect pests of many crops worldwide. Reference [35] stated that neem products are effective against more than 350 species of arthropods, 12 species of nematodes, 15 species of fungi, three viruses, two species of snails and one crustacean species. Some naturally occurring compounds have been isolated from neem plants and shown to be active against different species of insect pests. It is well recognised that azadirachtin is the active ingredient of neem [34].

Azadirachtin $\left(\mathrm{C}_{35} \mathrm{H}_{44} \mathrm{O}_{16}\right)$ is a tetranortriterpenoids (limonoids) which extractable from Azadirachta plant species. This compound in neem have insecticidal properties as an antifeedant, repellence, oviposition deterrent, molting inhibition and a growth retardant for a variety of insects and arthropods $[26,39,40,41]$. Although every plant part of the neem tree contains azadirachtin substance, but most of previous research stated that the substance was much more concentrated in the seed kernels [32,33]. It presence in the neem seed kernel is to the extent of $0.1 \%$ to $0.5 \%$ by weight. Besides the azadirachtin, neem also contains more than 20 compounds that responsible for the characteristics smell of crushed seeds and neem oil.

The increasing amount of research on insect-plant chemical interactions has unveiled the potential of utilizing botanicals insecticides in the form of secondary plant metabolites or allelochemicals [36]. These naturally occurring biocidal agents have been shown to be selective, readily biodegradable and safe to human. The neem tree has been proposed in this study as the azadirachtins of this tree have been recognised for their insecticidal properties. 


\section{Material and methods}

\subsection{Sampling location}

The samples were collected from irrigated lowland rice field of Federal Land Consolidation and Rehabilitation Authority (FELCRA) Seberang Perak which located within Kg. Gajah Sub-district, Perak. FELCRA was cover the area about 17,698 ha by planting two types of major crops; paddy and oil palm (Figure 1). Total area under paddy cultivation is about 4,656.57 ha of which 3,413.78 ha are under an estates central management and the rest under semi-estate management.

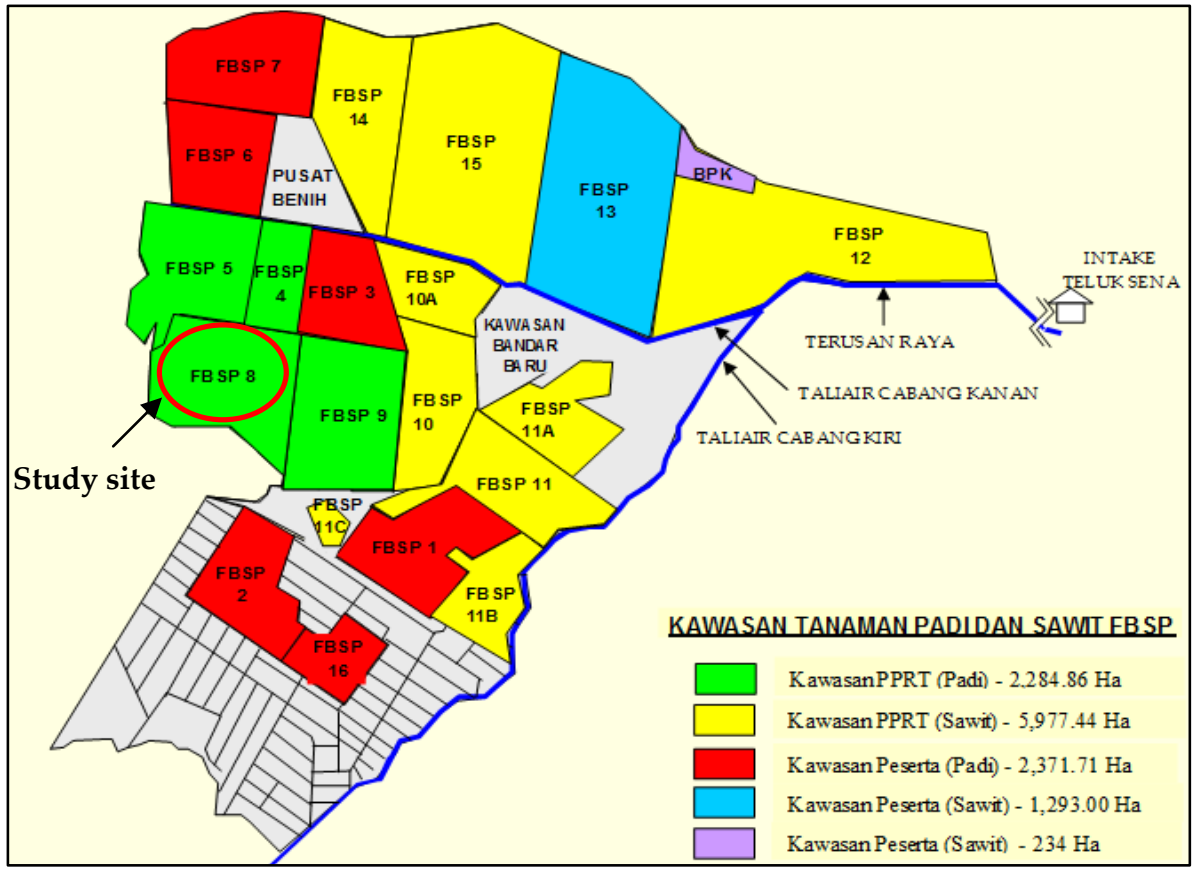

Source: Administration of FELCRA Seberang Perak (2009)

Figure 1. Map of FELCRA Seberang Perak that showing lot area for its two major crops

The sample collections of golden apple snail have been conducted from the lot FBSP 8 (Figure 1) with total area 712.59 ha (669 lots). The sampling collections were done at block L1B7 (191.94 ha). The leaves and seeds of neem were also collected from the surrounding area of FELCRA Seberang Perak. They were brought to the laboratory and placed in room temperature $\left(30-35^{\circ} \mathrm{C}\right)$ to dry and stored in an airtight container until used.

\subsection{Tested mollusc}

A population of golden apple snail were collected within the study area: L1B7- FELCRA Seberang Perak. Then, they were sorted for standard sizes (small and large) using a digital 
vernier caliper (range of $\pm 1 \mathrm{~mm}$ ) (Figure 2). The golden apple snails were assorted into size class with the size range within $20-40 \mathrm{~mm}$. The size of golden apple snail was selected by the height of shell which provided convenience in selecting snails of uniform size. These golden apple snail were used for the toxicity test in laboratory conditions.

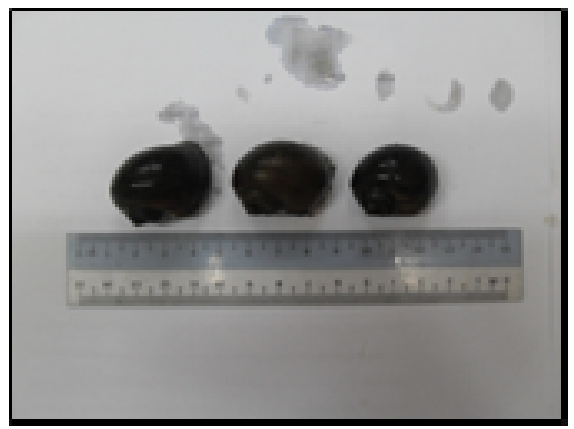

Small (20-30 mm)

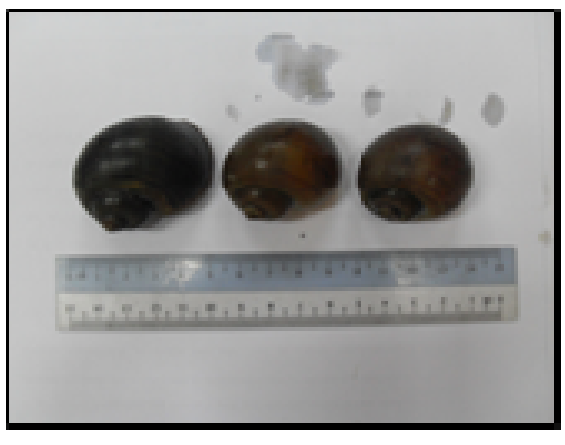

Large (30-40 mm)

Figure 2. Measurement of golden apple snail shell height for size determination

\subsection{Extraction procedure}

The concentrations used in the bioassays were prepared from raw plant parts extraction, in successive dilutions with distilled water (aqueous extract). Before the extraction process, the neem leaves and seed samples were air-dried at room temperature, and grounded into fine powder. Then, the fine powder was sieved for extraction. Crude plant extracts were prepared by filling up distilled water on weighed plant material to get desired concentration rate. The solution was left overnight and filtered through plastic net. Liquid detergent was added to the final extract to act as a surfactant. The solutions were independently sprayed on the plants and pure distilled water was used for control with the same volume of the solution.

\subsection{Toxicity test}

Two plant parts which is neem seeds and leaves in combinations with application of required concentration rates of neem extract solution including the control (untreated) were carried out on two different sizes of golden apple snail (Table 1). The results from rangefinder test were used to establish a more narrow concentration range for the definitive toxicity test. Once this range was determined, four narrow concentrations were developed to test the toxicity of leaves and seed crude extract and the experiment was replicated three times. A total of 135 golden apple snail with five snails per treatment were tested, which golden apple snail were exposed to the test substance in one plastic cage. Then, they were fed with 14 day-old of paddy seedlings that had been transplanted from nursery with 30 seedlings per plastic cage. A various concentrations of crude aqueous extract solutions from each of the raw materials were sprayed evenly on these paddy seedlings. After that, distilled water was flooded into the plastic cages to mimic the natural conditions for golden apple 
snail's growth. Mortality and survival of golden apple snail was assessed at 24, 48, 72 and 96 hours after treatment application. The mortality of the golden apple snail during the tests were confirmed by the opening of operculum and the head did not respond when pushed.

\begin{tabular}{|c|c|c|}
\hline Treatment & Neem plant parts & Concentration (\%) \\
\cline { 1 - 1 } $\mathrm{P}_{0} \mathrm{C}_{0}$ & \multirow{2}{*}{-nil- } & $\begin{array}{c}0 \\
\text { (water only) }\end{array}$ \\
\cline { 1 - 1 } $\mathrm{P}_{1} \mathrm{C}_{1}$ & \multirow{3}{*}{ Leaves } & 0.75 \\
\hline $\mathrm{P}_{1} \mathrm{C}_{2}$ & & 1.5 \\
\hline $\mathrm{P}_{1} \mathrm{C}_{3}$ & & 2.25 \\
\hline $\mathrm{P}_{1} \mathrm{C}_{4}$ & & 3.0 \\
\hline $\mathrm{P}_{2} \mathrm{C}_{1}$ & \multirow{3}{*}{ Seeds } & 0.75 \\
$\mathrm{P}_{2} \mathrm{C}_{2}$ & & 1.5 \\
\hline $\mathrm{P}_{2} \mathrm{C}_{3}$ & & 2.25 \\
\hline $\mathrm{P}_{2} \mathrm{C}_{4}$ & & 3.0 \\
\hline
\end{tabular}

Table 1. Experimental treatment on two different sizes of golden apple snail, small and large.

\subsection{Statistical analysis}

The observation on golden apple snail mortality was carried out for four consecutive days after treatment application and data was recorded based on the number of golden apple snail's mortality in every 24 hours up to 96 hours exposure period. For the toxicity test, the concentration-mortality regression analysis were developed using the mortality data of golden apple snail after 96 hours treatment. This regression analysis was conducted to determine the values of concentration of neem crude extract that caused $50 \%$ and $90 \%$ (LC50 and $\mathrm{LC}_{90}$ ) mortality of the golden apple snail. Probit Analysis was used to analyse statistically the data and calculated together with their $95 \%$ fiducial limits. Then, the variances within the treatments in terms of concentration of neem crude extract, type of plant parts and size of golden apple snail were evaluated in analysis of variance (ANOVA) by General Linear Model and when the significant differences were observed, further multicomparison test was applied through Pairwise comparison analysis. This analysis could determine which means were significantly different and classified them in a group. The $t-$ test at $95 \%$ confidence interval was used to compare LC 50 valued between neem leaves crude extract and neem seeds crude extract, and to compare LC 50 valued in different size of golden apple snail. Probit Analysis, ANOVA and t-test analysis were undertaken using the Minitab $^{\circledR} 14.1$ version (Minitab, Inc.).

\section{Result and discussion}

\subsection{Mortality of golden apple snail}

The mortality gathered from this experiment was used to identify the potential of each neem leaf and seed extracts in controlling golden apple snail. The percentages of mortality for 
both sizes (small and large) on the control treatment $\left(\mathrm{P}_{0} \mathrm{C}_{0}\right)$ were significantly lower than on all the neem-treated plants ( $\mathrm{p} \leq 0.005)$ (Table 2$)$. Approximately $6.7 \%$ of the golden apple snail mortality percentage on the control treatment for both sizes respectively, and those treated with aqueous neem extract is in the range of $89.5 \%$ to $92.9 \%$. The results showed that golden apple snail was susceptible to neem extraction as the golden apple snail mortality relatively high on the treated plants compared with the control treatment.

$\%$ mortality $=$ mean mortality in treatment - mean mortality in control

Mean mortality in treatment

\begin{tabular}{|c|c|c|}
\hline \multirow{2}{*}{ Treatment } & \multicolumn{2}{|c|}{ Percentage of mortality (\%) } \\
\cline { 2 - 3 } & Small golden apple snail & Large golden apple snail \\
\hline $\mathrm{P}_{0} \mathrm{C}_{0}$ & 6.7 & 6.7 \\
\hline $\mathrm{P}_{1} \mathrm{C}_{1}$ & 92.6 & 92.6 \\
\hline $\mathrm{P}_{1} \mathrm{C}_{2}$ & 92.9 & 91.3 \\
\hline $\mathrm{P}_{1} \mathrm{C}_{3}$ & 93.1 & 92.3 \\
\hline $\mathrm{P}_{1} \mathrm{C}_{4}$ & 92.6 & 89.5 \\
\hline $\mathrm{P}_{2} \mathrm{C}_{1}$ & 89.5 & 90.5 \\
\hline $\mathrm{P}_{2} \mathrm{C}_{2}$ & 90.5 & 89.5 \\
\hline $\mathrm{P}_{2} \mathrm{C}_{3}$ & 92.6 & 91.7 \\
\hline $\mathrm{P}_{2} \mathrm{C}_{4}$ & 89.5 & 90.9 \\
\hline
\end{tabular}

Table 2. Mortality of golden apple snail treated with different treatments.

Results obtained from these experiments noted that the aqueous neem extract has the potential to reduce golden apple snail infestation. According to reference [12], the tested of small-scale plot showed the neem treated plots had lower missing hill damage compared to control that plots, even the golden apple snail mortality is very low. Besides golden apple snail, neem tree extract also could help controlling other paddy insect pests as it is typically control a broad-spectrum of pests. This can result in the need for use of additional application of pesticides.

\subsection{Mortality pattern of golden apple snail}

The mortality pattern as a result of the exposure of different size ranges of golden apple snail to different concentrations with different neem plant parts is demonstrated. Data mortality of the snail was taken every 24-hours interval in four days and the results were shown in Figure 3 and 4. The analysis of data demonstrated in Figure 3 and Figure 4 as distribution of golden apple snail mortality in relation with the time and different treatment concentrations for both neem plant parts.

Based on the observations, it showed that the effectiveness of neem extract on the snail tested was both relatively slow and not highly varies and took 72 to 96 hours to reach endpoint mortality. The findings were contradicted to that finding by [12], where the 48 hours 


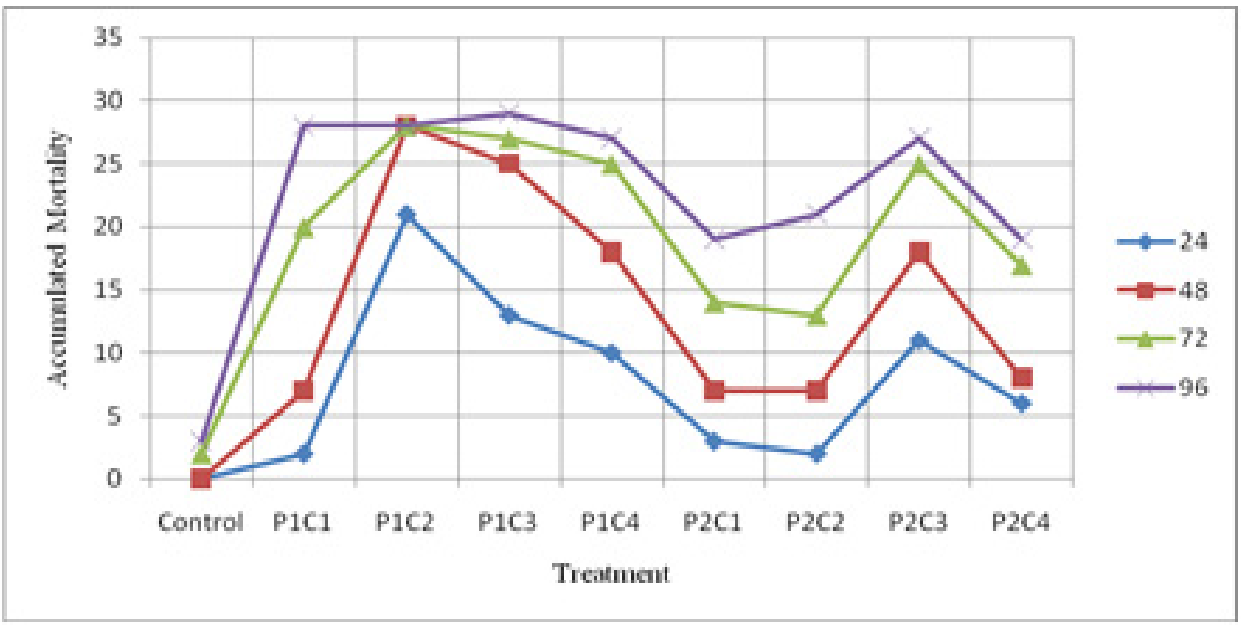

Figure 3. Accumulated mortality of small golden apple snail on different treatments

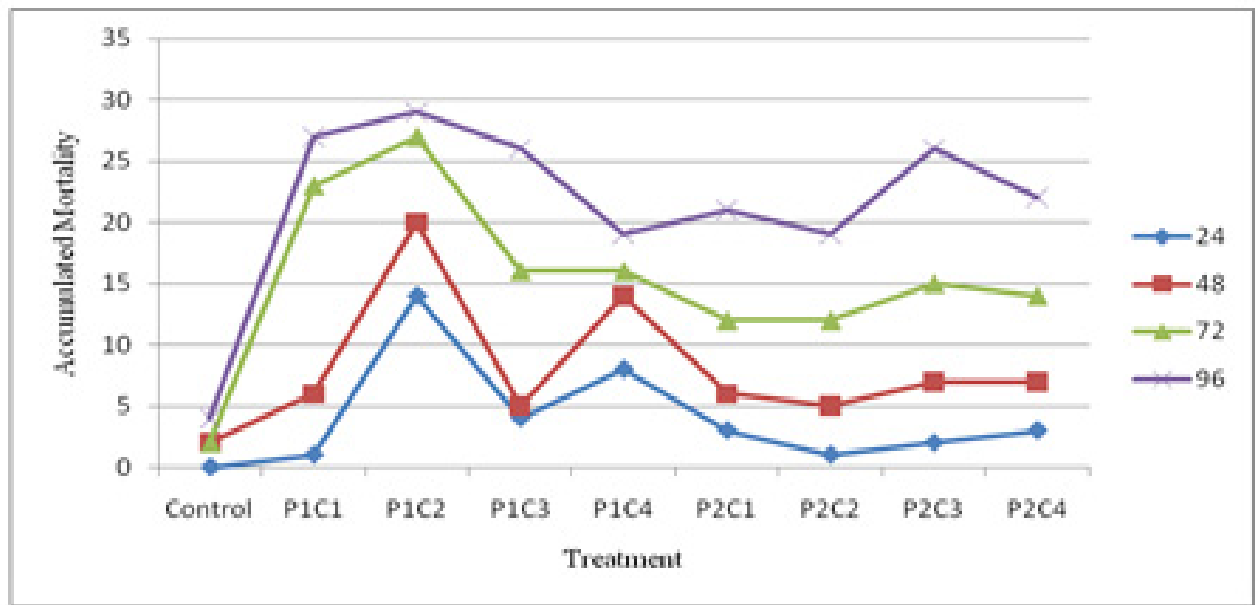

Figure 4. Accumulated mortality of mixed sizes of golden apple snail on different treatments

as end-point mortality for golden apple snail. However, a similar situation was also observed in another study [38] which neem tree leaf extract was killed $95.83 \%$ of golden apple snail in 95 hours. Reference [42] was stated that the effectiveness varies according to the insect pest species, its life stage and environmental factors.

In this study, the effectiveness of neem extracts varies for between the plant parts tested and the small size and large size of golden apple snail for the same plant parts. Results from the studies demonstrated small sizes of golden apple snail were highly mortality $(25.19 \%)$ at 24 hours and $24.07 \%$ at 72 hours for large sizes of golden apple snail. These results were due to 
different food intake rates between the small and large golden apple snail. The mortality of small golden apple snail was higher and faster than that the large golden apple snail as small golden apple snail has high appetite for development process. This result agreed to that reference [43], who found that smaller golden apple snail had a greater relative foraging capacity on macrophytes than adult. They also added that the juvenile of golden apple snail could consume an approximately 12 times more resources by mass than adults.

Different parts of neem plant also express different potencies of molluscicides. Thus, the golden apple snail mortality was also comparable to the different plant parts which $93.33 \%$ of small golden apple snail was dead with leaves crude extract and only $71.67 \%$ in seeds crude extract. For the large sizes of golden apple snail, $84.17 \%$ was dead in leaves crude extract and $73.33 \%$ when treated with neem seeds crude extract. This can be stated that leaves crude extract are more effective compared to the seeds crude extract in controlling small golden apple snail. A similar situation happened in controlling large sizes of golden apple snail, but the mortality rate for small golden apple snail was much larger than large golden apple snail.

The evaluation on the molluscicidal test data of aqueous neem extract was revealed that the plant parts vary considerably in their degree of activities. Result from the studies shows that the aqueous neem leaves crude extract was more effective than neem seeds crude extract for both sizes of golden apple snail. However, reference [22] classified the seeds had the highest molluscicidal toxicity than the leaves on the death of $80-100 \%$ at 48 hours for different concentrations. Furthermore, reference [12] also added that, among the aqueous extracts, neem leaf extract was the least toxic even at $0.1 \%$.

\subsection{Analysis of variance (ANOVA) in experimental treatment}

The analysis of variance within treatments in term of concentrations of neem crude extract, different types of neem plant parts and sizes of golden apple snail were analysed statistically by determination of ANOVA using General Linear Model (GLM). Then, when the significant difference was observed, further multi-comparison test was applied through Pairwise comparison analysis to determine means were significantly different and classified into groups.

From the analysis of variance in Table 3 was obtained the F-statistic of 7.08 with p-value is 0.000 and Table 4 with the F-statistic of 3.93 , p-value is 0.008 . This value indicates that there are very strong evidences to suggest that the means of variable for small and large sizes of golden apple snails are not similar to each other and it required discovering which treatment has significantly difference in means.

\begin{tabular}{|c|c|c|c|c|c|c|}
\hline Source & DF & Seq SS & Adj SS & Adj MS & F & P \\
\hline Treatment & 8 & 192.963 & 192.963 & 24.120 & 7.08 & 0.000 \\
\hline Error & 18 & 61.333 & 61.333 & 3.407 & & \\
\hline Total & 26 & 254.296 & & & & \\
\hline
\end{tabular}

Table 3. Analysis of variance for treatments application on small sizes of golden apple snail. 


\begin{tabular}{|c|c|c|c|c|c|c|}
\hline Source & DF & Seq SS & Adj SS & Adj MS & F & P \\
\hline Treatment & 8 & 146.667 & 146.667 & 18.333 & 3.93 & 0.008 \\
\hline Error & 18 & 84.000 & 84.000 & 4.667 & & \\
\hline Total & 26 & 230.667 & & & & \\
\hline
\end{tabular}

Table 4. Analysis of variance for treatments application on large sizes of golden apple snail.

Figures 5 and 6 summarize the results of Tukey's Simultaneous Test (Pairwise comparison) for all the tested neem concentrations for both plant parts against the golden apple snail. The results indicate that leaves and seeds of neem plants extracts were significantly effective than the control treatment. A comparison of treated plants with control revealed significant difference in the number of mortality for golden apple snail. In Figure 5, shows that the mean level for control treatment $\left(\mathrm{P}_{0} \mathrm{C}_{0}\right)$ is significantly the lowest among other treatments, while Figure 6 shows the mean level for $\mathrm{P}_{0} \mathrm{C}_{0}$ is lower than other six treatments except for $\mathrm{P}_{1} \mathrm{C}_{4}$ and $\mathrm{P}_{2} \mathrm{C}_{2}$. However, another treatment was not significantly different from each other.

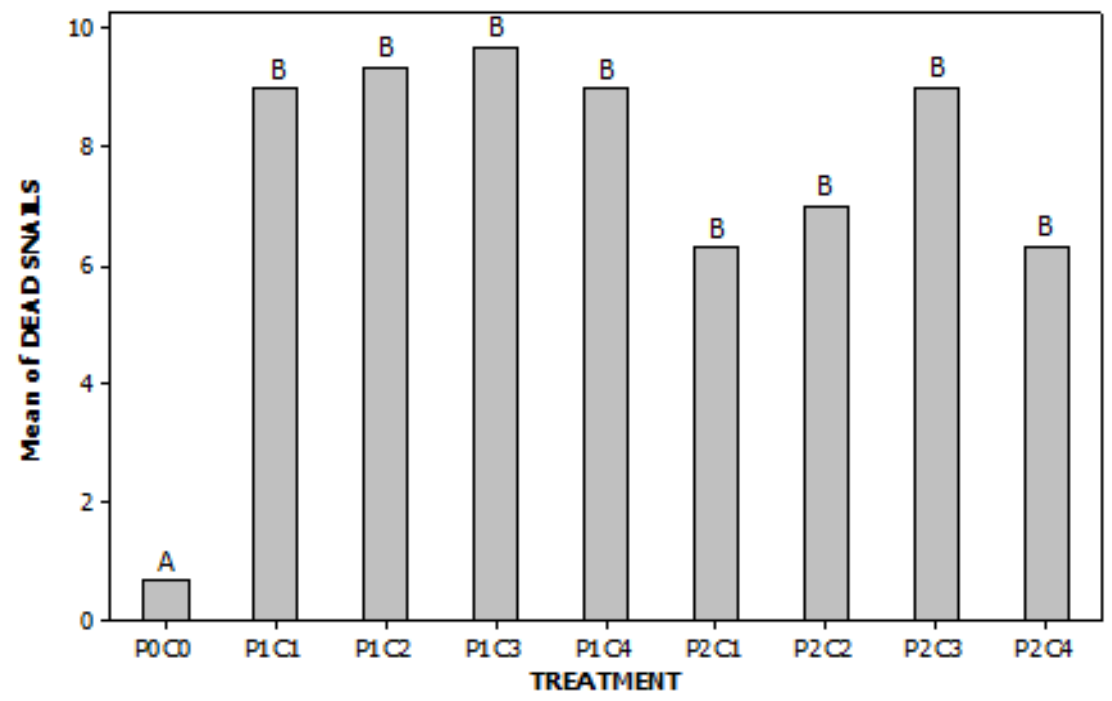

Figure 5. Pairwise comparisons among levels of treatment on small sizes of golden apple snail.

The comparison of the different treatments revealed that the neem has a positive effect against golden apple snail. Findings from the study suggested that the neem tested had a feeding deterrent effect on the golden apple snail. Reference [12], while studying the effect of Phytolacca dodecandra and Azadirachta indica on the reproduction of the golden apple snail reported that their active molluscicidal compounds such as triterpenoid and azadirachtin [34] caused a significant reduction in the survival of young and matured golden apple snail. The compounds have many properties including insecticidal activity, antifeedant, acting as a phago- and oviposition deterrent [36], growth retardant, moulting inhibitor, and sterilant as well as having anti-fungal, anti-viral and anti-bacterial properties against pathogens [33]. 


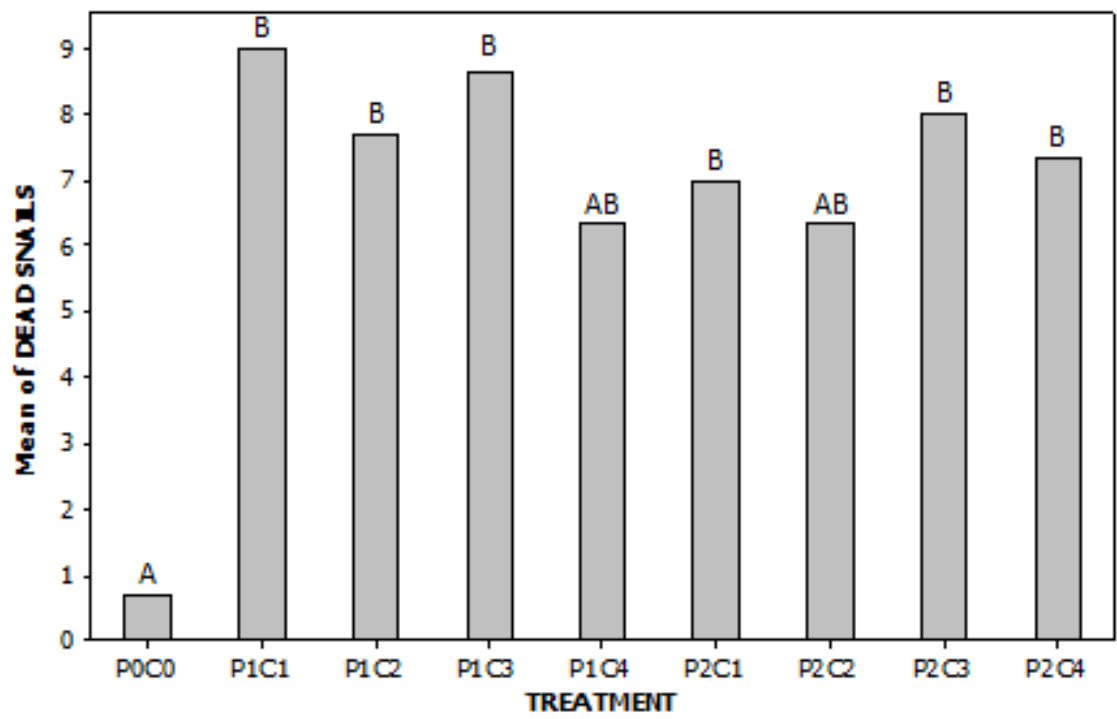

Figure 6. Pairwise comparisons among levels of treatment on large sizes of golden apple snail.

\section{4. $L_{50}$ value of neem crude extract}

Table 5 and 6 summarize the results on the effect of neem leaves and seeds aqueous crude extract to two different golden apple snail's mortality. Results from Table 5 indicate that the estimate of the $\mathrm{LC}_{50}$ value for neem leaves crude extract against small golden apple snail is $0.442 \%$ with a $95 \%$ confidence interval (CI) of $(0.012-0.743 \%)$ while for neem seeds crude extract is $1.036 \%$ with a $95 \%$ CI of $(0.444-1.456)$. The LC 50 value in large golden apple snail for neem leaves crude extract is $0.498 \%$ with a $95 \%$ CI of $(-0.714-1.065 \%)$ and 1.045 with a $95 \%$ CI of $(0.489-1.449 \%)$ for neem seeds crude extract (Table 6$)$.

\begin{tabular}{|c|c|c|c|}
\hline Neem plant parts & Conc. (\%) & $\begin{array}{c}C_{50}(\%) \\
95 \% \text { CI }\end{array}$ & $\begin{array}{c}\mathrm{LC}_{95}(\%) \\
95 \% \mathrm{CI}\end{array}$ \\
\hline \multirow{4}{*}{ Leaves } & 0.75 & \multirow{2}{*}{$\begin{array}{c}\mathbf{0 . 4 4 2} \\
(0.012-0.743)\end{array}$} & \multirow{2}{*}{$\begin{array}{c}2.266 \\
(1.878-2.912)\end{array}$} \\
\hline & 1.5 & & \\
\hline & 2.25 & & \\
\hline & 3.0 & & \\
\hline \multirow{4}{*}{ Seeds } & 0.75 & \multirow{2}{*}{$\begin{array}{c}1.036 \\
(0.444-1.456) \\
\end{array}$} & \multirow{2}{*}{$\begin{array}{c}4.279 \\
(3.391-6.282)\end{array}$} \\
\hline & 1.5 & & \\
\hline & 2.25 & & \\
\hline & 3.0 & & \\
\hline
\end{tabular}

Note: $\mathrm{CI}=$ Confidence Interval; LC=Lethal Concentration

Table 5. Toxicity of neem crude extract against small sizes of golden apple snail 


\begin{tabular}{|c|c|c|c|}
\hline Neem plant parts & Conc. $(\%)$ & $\begin{array}{c}\mathrm{LC}_{50}(\%) \\
95 \% \mathrm{CI}\end{array}$ & $\begin{array}{c}\mathrm{LC}_{95}(\%) \\
95 \% \mathrm{CI}\end{array}$ \\
\hline \multirow{4}{*}{ Leaves } & 0.75 & \multirow{2}{*}{$\begin{array}{c}\mathbf{0 . 4 9 8} \\
(-0.714-1.065) \\
\end{array}$} & \multirow{2}{*}{$\begin{array}{c}4.632 \\
(3.469-8.007) \\
\end{array}$} \\
\hline & 1.5 & & \\
\hline & 2.25 & & \\
\hline & 3.0 & & \\
\hline \multirow{4}{*}{ Seeds } & 0.75 & \multirow{2}{*}{$\begin{array}{c}\mathbf{1 . 0 4 5} \\
(0.489-1.449) \\
\end{array}$} & \multirow{2}{*}{$\begin{array}{c}4.149 \\
(3.307-6.001) \\
\end{array}$} \\
\hline & 1.5 & & \\
\hline & 2.25 & & \\
\hline & 3.0 & & \\
\hline
\end{tabular}

Note: $\mathrm{CI}=$ Confidence Interval; $\mathrm{LC}=$ Lethal Concentration

Table 6. Toxicity of neem crude extract against large sizes of golden apple snail

Based on the LC 50 values after 96 hours exposure period, the aqueous extract of neem leaves demonstrated more potent molluscicidal activity than neem seeds aqueous extract, which can be attributed to the different extracting plant parts. Comparison of the LC 50 and $\mathrm{LC}_{95}$ of aqueous neem crude extract on leaves and seeds at 96 hours exposure showed that, golden apple snails were more sensitive against the aqueous leaves crude extract than that aqueous seeds crude extract. The aqueous extract of the neem leaves was 2.34 and 2.10 times more toxic than those from the seeds against small and mixed sizes of golden apple snail, respectively.

Finding from this study was contradicted to that study by reference [12], aqueous neem seed extract was more toxic than neem leaves extract. The seed extract was also the most toxic and causing $100 \%$ mortality after 24 hours of exposure at 20,000 ppm for both golden apple snail size and the neem leaf extract the least toxic that caused $100 \%$ mortality at $30,000 \mathrm{ppm}$ and 40,000 ppm for small and mixed golden apple snail sizes, respectively. Reference [22] found that, the seed extract has high toxicity with toxic more than 200-1,000 ppm and leaves extract was in inactive status when the toxicity more than 10,000 ppm.

The factor causing differences in the findings probably due to the azadirachtin content in each of the different neem plant parts. All parts of the neem tree contain azadirachtin, and more concentrated in the seed kernel $[32,33]$. Finding of the study was expected considering the fact that the content of azadirachtin in neem tree varies greatly between locations and other factors may also contribute to variability [42]. Difference in trees maturity, application technique and perhaps environmental factors would probably contribute to these inconsistencies. This study did not analyze on the active ingredient from prepared the extract; however, it is possible that the azadirachtin content in seeds and leaves could raise the efficiency of extraction.

Results from the research also demonstrated that, snail mortality using the neem extracts at 96 hours was dependent on the sizes of golden apple snail's sizes. The higher lethal 
concentration was observed in the large golden apple snail's size $(30-40 \mathrm{~mm})$ than the small golden apple snail $(20-30 \mathrm{~mm})$, which suggesting that lethal concentration increased as the size of the golden apple snail is increased. A similar situation was also observed in another study [12] where the leaf extract caused $100 \%$ mortality at 30,000 ppm for small golden apple snail and 40,000 ppm for mixed sizes of golden apple snail. Reference [44] was stated that, the size of golden apple snail at $10 \mathrm{~mm}$, started eating paddy plants. Therefore, control measures should be implemented when the size of the golden apple snails was smaller or younger stage to reduce crop losses by using lower concentration of neem extract.

\subsection{Correlation between treatment and size of golden apple snail}

The interaction between treatments can be visualized by plotting the number of snail mortality as dependent variable against two types of plant part with one line for each level of the concentration as illustrated in the Figure 7 and 8 . As the difference between any leaves and seeds means changes with the concentration level; which the leaves were the high ranking in the observation for both sizes of golden apple snail.

The interaction plot in Figure 7 indicates that the ordinal interaction as the lines is not parallel. The difference between neem leaves and neem seeds extracts was essentially close for concentration $2.25 \%$, whereas the difference on concentrations $0.75 \%$ and $3.0 \%$ ppm was much larger for the neem leaves crude extract than that neem seeds crude extract.

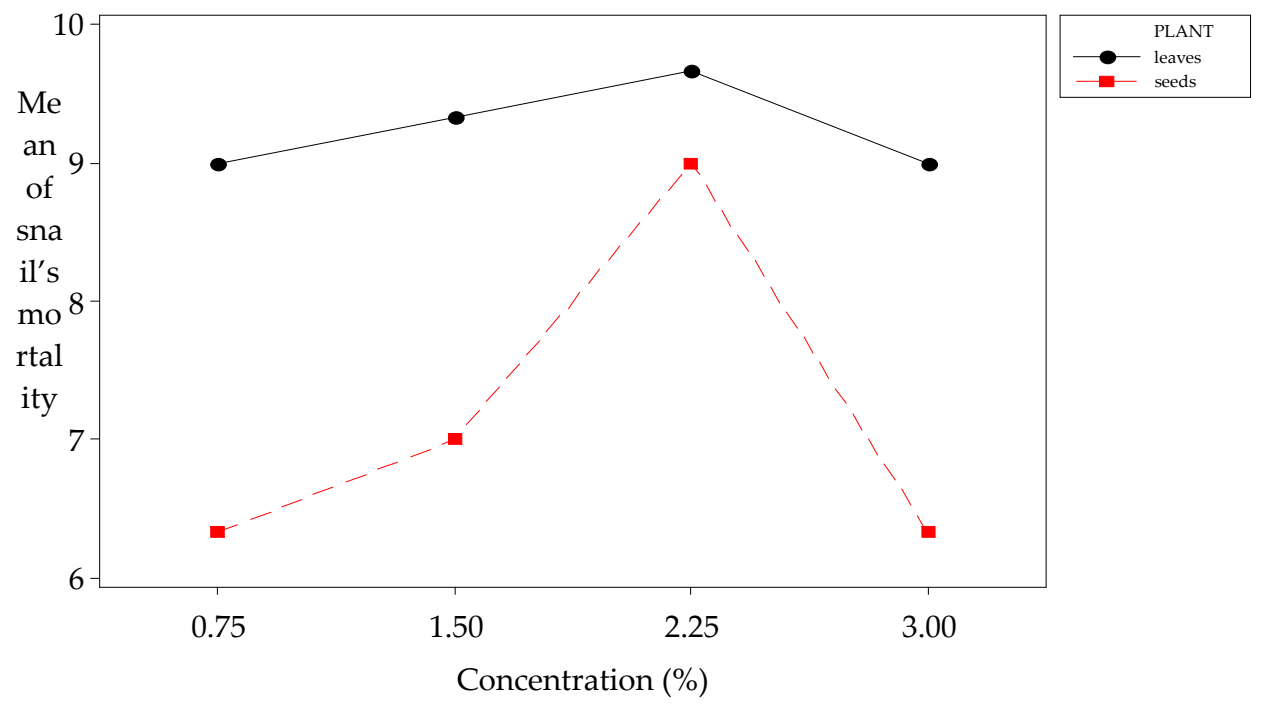

Figure 7. Interaction plot for treatment and mortality rate of small golden apple snail 
Figure 8 shows the lines are not parallel but crossed each other; mean that there is an interaction. From examining this interaction plot, it appears that neem leaves crude extract has the highest mortality rate compared to the neem seeds crude extract for three different concentrations of $0.75 \%, 1.5 \%$ and $2.25 \%$ ppm. However, it was not for concentration $3.0 \%$ where as neem seed extract higher than neem leaves extract.

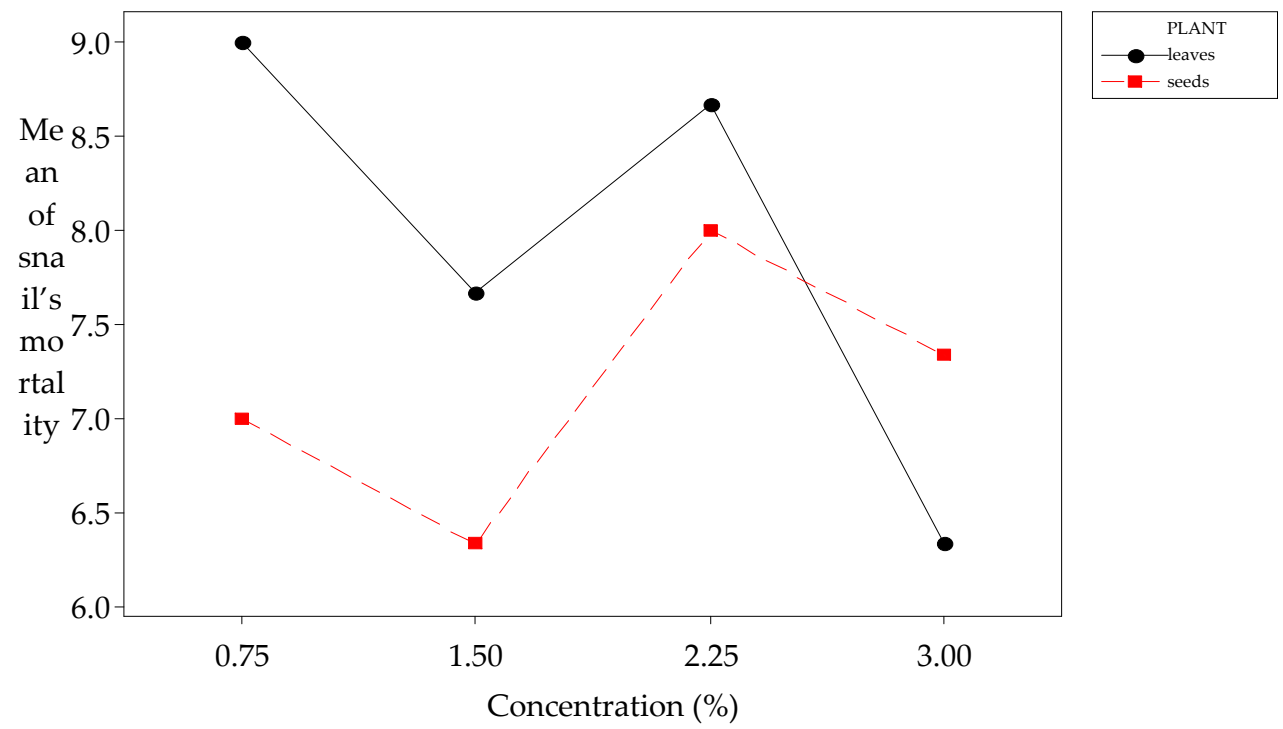

Figure 8. Interaction plot for treatment and mortality rate of mixed sizes of golden apple snail

\section{Conclusion}

The comparisons of LC50 values between neem leaves and seeds extract were not substantially different from each other and it showed no significant difference (T-test: 0.56; $\mathrm{p}=0.677$ and T-test: $0.86 ; \mathrm{p}=0.549$ ). However, aqueous neem leaves extract have the potency in controlling both sizes of golden apple snail in using low concentration compared to aqueous neem seeds extract. The $\mathrm{LC}_{50}$ value of aqueous neem leaves extract after 96 hours exposure period was 2.34 times and 2.10 times more toxic than those from the seeds for small and large sizes of golden apple snail, respectively. On the other hand, aqueous neem leaves extract was caused high snail mortality with $93.33 \%$ and $84.17 \%$ of small and large size of golden apple snail was dead compared to aqueous seeds crude extract, $71.67 \%$ and $73.33 \%$ respectively. In the context of effectiveness, neem leaves extract also showed the ability to cause high mortality in a shorter time than seeds crude extract by killed $38.3 \%$ of the small golden apple snail within 24 hours and $30.83 \%$ at 72 hours for large sizes of golden apple snail, while neem seed extract was only $24.17 \%$ at 72 hours and $29.17 \%$ at 96 hours for small and large size of golden apple snail, respectively. 
From the result, both plant parts have ability in controlling golden apple snail but aqueous neem leaves extract was expressed the effectiveness as a molluscicide than neem seeds extract for both size of golden apple snail.

In this study, all the tested neem concentrations for both plant parts affected the golden apple snail mortality (small and large) and were significantly different from the control treatment (ANOVA: $\mathrm{F}=7.08, \mathrm{p}=0.000$ for small snail and $\mathrm{F}=3.93, \mathrm{p}=0.008$ for large size of golden apple snail). The result was revealed that control treatment caused the lowest mortality number of golden apple snail among other treatments. However, the four concentrations for the extraction of leaves and seeds showed no significant difference in the mortality rate of golden apple snail.

Toxicity study of neem leaves and seeds crude extract in small and large size of golden apple snail exhibited the statistically not significant difference of the $\mathrm{LC}_{50}$ values between two different sizes of golden apple snail (T-test: - 1.02; $\mathrm{p}=0.494$ and T-test: $-1.02 ; \mathrm{p}=0.494$ ). Half of the small golden apple snail populations were appeared to be affected by the neem leaves extract at $0.442 \%$ and $1.036 \%$ for neem seed extract. While for large size of golden apple snail, the concentration of neem leaves extract at $0.498 \%$ and $1.045 \%$ for neem seed extract was needed to cause $50 \%$ mortality of golden apple snail. The higher lethal concentration was observed in the large size of golden apple snail than the small golden apple snail, which suggesting that lethal concentration increased as the size of the golden apple snail is increased. Therefore, the neem crude extract application to small golden apple snail is the appropriate application because the farmer can use the lower concentration for crop damage protecting. In the observation of the speed of action of neem extracts, the study was showed that $25.19 \%$ of the small sizes of golden apple snail were highly dead at 24 hours and $24.07 \%$ at 72 hours for large sizes of golden apple snail.

In conclusion, the molluscicidal potential of neem has been proven, beyond doubt by the present investigations. This both neem plant parts can be used as alternative molluscicides to harmful synthetic chemical molluscicides that are widely used today to eradicate unwanted golden apple snail in the paddy field. Utilization of neem-based biopesticide early in the rice growing season when young golden apple snail at the predominant life stage would provide effective control and, due to their minimal effects on other aquatic life will reduce the resurgence problem that always occurred when chemical molluscicides are used early in the rice growing season. Therefore, the use of neem as molluscicides are highly recommended because they are toxicologically safe, environment friendly, easy to use and have a wide range of insecticidal activity.

The research has attempted to provide some information on the potential and toxicity of neem trees against the golden apple snail. In addition, this research also provides an idea for the development of locally produced, cheaper and safer biopesticide formulation which its application can provides an alternative way for synthetic pesticide application in pest management control at paddy field. Therefore, the results gathered from this research need to be confirmed on paddy field trial site, as well as investigate the environment impact from the extract application by determining the acute toxicity effect and chronic toxicity effect on 
non-target organism such as fish. It is also recommended to extend neem extraction research to other extraction solvent and method, as solvent and extraction procedure may largely influence azadirachtin production. Moreover, the evaluations in this study were done using determination of golden apple snail mortality and different amount of organic compound in neem might influence the pesticidal activities of neem on golden apple snail. The study on the mechanism or mode of action of neem crude extract on golden apple snail should be tested to ensure the main factor of golden apple snail mortality.

\section{Author details}

Siti Noor Hajjar Md Latip and Rosdiyani Massaguni

Faculty of Plantation and Agrotechnology, Universiti Teknologi MARA, Shah Alam, Selangor, Malaysia

\section{Acknowledgement}

This work was supported by funds from the Ministry of Higher Education (MOHE), Malaysia through Fundamental Research Grant Scheme (FRGS) 600RMI/ST/FRGS5/3/Fst(270/2010 - Potential of Neem, Azadirachta indica for controlling the golden apple snail, Pomacea canaliculata headed by Dr. Siti Noor Hajjar Md Latip.

\section{References}

[1] Mukhlis. Z.A. (2009). Food Security and Poverty Alleviation in the Millennium Development Goals: The Role of Muda Irrigation Project In: 14 $4^{\text {th }}$ MANCID Annual Conference. $14^{\text {th }}-15^{\text {th }}$ February 2009. Merdeka Palace Hotel, Kuching, Sarawak, Malaysia

[2] Du, L. N., Jonathan, D., Chen, X.Y., Cui, G. H., an Yang, J. X., (2007). A record of the invasive Golden Apple Snail, Pomacea canaliculata (Lamarck 1819) at Black Dragon Spring, Dianchi Basin. In: Zoological Research 28(3): 325-328

[3] Teo, S. S., (2004). Biology of the golden apple snail, Pomacea canaliculata (Lamarck, 1822), with emphasis on responses to certain environmental conditions in Sabah, Malaysia. Molluscan Research 24 (2004) 139-148. Available online at: www.publish.csiro.au/journal/mr

[4] Liu, W.H., Chiu, Y.W., Huang, D.J., Liu, M.Y., Lee, C.C., and Liu L.L., (2006). Imposex in the golden apple snail Pomacea canaliculata in Taiwan. Journal of Science of the Total Environment 371: pp 138-143.

[5] San Martin,R., Ndjoko, K., and Hostettmann, K., (2008). Novel molluscicide against Pomacea canaliculata based on quinoa (Chenopodium quinoa) saponins. Crop Protection 27 (2008) 310-319

[6] Teo, S.S., (1999). Control of the Golden Apple Snail in Irrigated Rice by Irrigated Approach in Sabah. In: 5th International Conference on Plant Protection in the Tropics. 15- 18 March 1999, Kuala Lumpur, Malaysia 
[7] Joshi, R., C. (2005). Mini Review: Managing invasive alien mollusc species in rice.

[8] Ito, K., (2002). Environmental factors influencing overwintering success of the golden apple snail, Pomacea canaliculata (Gastropoda: Ampullariidae), in the northernmost population of Japan. Appl. Entomol. Zool. 37 (4): 655-661

[9] Schnorbach H-J. 1995. The golden apple snail (Pomacea canaliculata Lamarck), an increasingly important pest in rice, and methods of control with Bayluscid. Pflanzenschutz-Nachrichten Bayer 48:313-346

[10] Naylor, R., (1996). Invasions in agriculture: assessing the cost of the golden apple snail in Asia. AMBIO 25(7):443-448.

[11] Sanico, A.L., Peng, S., Laza, R.C. and Visperas, R.M., (2002). Effect of seedling age and seedling number per hill on snail damage in irrigated rice. Crop Protection 21 (2002) 137-143

[12] Maini, P.N., and Rejesus, B.M., (1993a). Antifeedant activity of the crude and formulated products from Azadirachta indica to golden apple snail (Pomacea Spp.). In: The Philippine journal of science Vol.122 No.1.

[13] Cowie, R.H., (2002). Apple snails as agricultural pests: their biology, impacts, and management. In: Molluscs as Crop Pests (ed. G.M. Barker), p. 145-192. CABI Publishing, Wallingford.

[14] Adalla, C.B., and Rejesus B.M., (1989). The Golden Apple Snail, Pomacea sp., a serious pest of the lowland rice in the Philippines. In: Henderson I, editor. Slugs and Snails in World Agriculture. British Crop Protection Council Monograph No. 41. Thornton Heath: BCPC. p 417 -427.

[15] Mochida, O., (1988). Nonseedborne rice pests of quarantine importance. In: IRRI "Rice seed health". p117-129

[16] Teo, S. S., (2001). Evaluation of different duck varieties for the control of the golden apple snail (Pomacea canaliculata) in transplanted and direct seeded rice. Crop Protection 20 (2001) 599-604. Available online at: www.elsevier.com/locate/cropro

[17] Dela Cruz M S, Joshi R C and Martin E C. (2000). Potential effects of commercial molluscicides used in controlling golden apple snalts on the native snail Vivipara costata (Quoy and Gaimard). Philipp. Ent. 14(2): 149-157

[18] Dela Cruz, M.S., and Joshi, R.C., (2001). Efficacy of commercial molluscicide formulations against the golden apple snail Pomacea canaliculata (Lamarck). In: The Philippine Agricultural Scientist Vol. 84 No. 1 (Jan.-Mar. 2001).

[19] Akhtar, Y., Yeoung, Y.R., and Isman, M., (2008). Comparative bioactivity of selected extracts from Meliaceae and some commercial botanical insecticides against two noctuid caterpillars, Trichoplusia ni and Pseudaletia unipuncta. Phytochem Rev 7:77-88

[20] Rejesus, B.M., Sayaboc A.S., and Joshi, R.C., (1988). The distribution and control of the introduce golden snail (Pomacea sp.) in the Philippines. In: Proc. of the Symp. on the Introduction of Germplasm and Plant Quarantine Procedures, Kuala Lumpur (Malaysia), 14-15 Dec. 1988. p213-223.

[21] Maini, P.N., and Rejesus, B.M., (1993b). Molluscicidal activity of Derris elliptica (Fam. Leguminose). In: Philippine Journal of Sciences. p1-14 
[22] Rejesus, H.M., and Punzalan, E.G., (1997). Molluscicidal action of some Philippine plants on golden apple snail, Pomacea spp. Philipp. Ent. 11(1): 65-79

[23] Ndamba, J., Robertson, I., Iemmich, E., Chandiwana, S. K., Furu, P. and Molgaard, P. (1994). Investigation of the diurnal, ontogenic and seasonal variation in the molluscicidal saponin content of Phytolacca dodecandra aqueous berry extracts. Phytochemistry, 35, [95-99].

[24] Charleston, D.S., Kfir, R., Dicke, M., and Vet, L.E.M., (2005). Impact of botanical pesticides derived from Melia azedarach and Azadirachta indica on the biology of two parasitoid species of the diamondback moth. Journal Biological Control 33, p.131-142

[25] Opolot, H.N., Agona, A., Kyamanywa, S., Mbata, G.N., and Adipala, E., (2006). Integrated field management of cowpea pests using selected synthetic and botanical pesticides. Journal of Crop Protection 25, p.1145-1152

[26] Mala, S., and Muthalagi, S., (2008). Effect of Neem oil Extracive (NOE) on Repellency, Mortality, Fecundity, Development and Biochemical Ananlysis of Pericallia ricini (Lepidoptera:Arctidae)

[27] Musman M. (2010). Toxicity of Barringtonia racemosa (L.) Kernel Extract on Pomacea canaliculata (Ampullariidae). Tropical Life Sciences Research, 21(2), p33-43.

[28] Baskar, K., Maheshwaran, R., Kingsley, S. and Ignacimuthu, S., (2011). Bioefficacy of plant extracts against Asian army worm Spodoptera litura Fab. (Lepidoptera: Noctuidae). Journal of Agricultural Technology 2011 Vol. 7(1): 123-131

[29] Chowdhary, A., and Singh, V., (2008). Chapter 2: Geographical distribution, ethnobotany and indigenous uses of neem. In: Neem: A Treatise. Singh, K.K., Phogat, S., Tomar, A., and Dhillon, R.S. (eds). Published by I.K International Publishing House Pvt. Ltd. p546.

[30] Arora, R., Singh, S., and Sharma, R.K. (2008). Neem Leaves: Indian Herbal Medicine. In: Watson, R.R. and Preedy, V.R. (eds). Botanical medicine in clinical practice. Published by CABI International 2008. p885

[31] Csurhes, S., (2008).Pest plant risk assessment: Neem Tree, Azadirachta indica. Available at: www.dpi.qld.gov.au/...EnvironmentalPests/IPA-Neem-Tree-Risk-Assessment.pdf

[32] Tomar, A. and Singh, K.K., (2008). Chapter 1: Neem: An Introduction. In: Neem: A Treatise. Singh, K.K., Phogat, S., Tomar, A., and Dhillon, R.S. (eds). Published by I.K International Publishing House Pvt. Ltd. p546

[33] Boeke, S.J., Boersma, M.G., Alink, G.M., Van Loon, J.J.A., Van Huis, A, Dicke, M., and Rietjens, I.M.C.M., (2004). Safety evaluation of neem (Azadirachta indica) derived pesticides. Journal of Ethnopharmacology 94 p25-41

[34] Yu, S.J., (2008). Chapter 5: Evaluation of toxicity. In: The toxicology and biochemistry of insecticides. Published by: CRC Press Taylor \& Francis Group. p87-100

[35] Girish, K., and Shankara, B.S., (2008). Neem- A green treasure. Electronic journal of Biology, Vol. 4(3): 102-111.

[36] Senthil-Nathan, S., Choi, M.N., Paik, C.H., Seo, H.Y., and Kalavani, K., (2009). Toxicity and physiological effects of neem pesticides applied to rice on the Nilaparvata lugens Stål, the brown planthopper. Ecotoxicology and Environmental Safety 72 (2009) 17071713 
[37] Pathak, M.D., and Khan, Z.R., (1994). Insect pest of rice. International Rice Research Institute, International Centre of Insect Physiology and Ecology. p89

[38] Benchawattananon, R., and Boonkong, U., (2006). The toxicity of leave crude extract from neem tree (Azadirachta indica Juss.) and Garlic (Allium sativom L.) on mortality rate of golden apple snail (Pomacea sp.), 32nd Congress on Science and Technology of Thailand. Queen Sirikit National Convention Center, Bangkok

[39] Lale, N.E.S., and Abdulrahman, H.T., (1999). Evaluation of neem (Azadirachta indica A. Juss) seed oil obtained by different methods and neem powder for the management of Callosobruchus maculatus (F.) (Coleoptera: Bruchidae) in stored cowpea. Journal of Stored Products Research 35, p.135-143

[40] Seljåsena, R. and Meadow, R., (2005). Effects of neem on oviposition and egg and larval development of Mamestra brassicae L: Dose response, residual activity, repellent effect and systemic activity in cabbage plants. Crop Protection 25 (2006). p338-345

[41] Rimpi, D, Chutia, B. C., Sarmah, M., and Rahman, A.,(2010). Effect of neem kernel aqueous extract (NKAE) on growth and development of red slug caterpillar, Eterusia magnifica butl in tea in North-East India, India. Journal of Biopesticides, 3(2): 489 - 494

[42] Lim, G.S., and Dale, G.B., (1994). Neem Pesticides in Rice: Potential and Limitations. Published by: International Rice Research Institute. p69. ISBN 971-11-0047-7.

[43] Boland, B.B., Meerhoff, M., Fosalba, C., Mazzeo, N., Barnes, M.A., and Burks, R.L., (2007). juvenile snails, adult appetites: contrasting resource consumption between two species of applesnails (Pomacea). Journal of Molluscan Studies pp. 1-8

[44] Philippine Rice Research Institute (PhilRice), (2001). Management options for the golden apple snail. Rice Technology no. 33. Department of Agriculture-PhilRice. Maligaya Muñoz, Nueva Ecija. p12 